\title{
A STUDY OF THE DIAMONDS, DIAMOND INCLUSION MINERALS AND OTHER MANTLE MINERALS FROM THE SWARTRUGGENS KIMBERLITE DYKE SWARM, SOUTH AFRICA
}

\author{
Neil Mc Kenna ${ }^{1}$, John J. Gurney ${ }^{2}$ and Jim M. Davidson ${ }^{3}$ \\ ${ }^{1}$ De Beers Consolidated Mines Limited; ${ }^{2}$ University of Cape Town, South Africa; ${ }^{3}$ Helam Diamond Mine, South Africa
}

The Swartruggens Kimberlite Dyke Swarm is situated approximately $60 \mathrm{~km}$ west of the town of Rustenburg in the North West Province of South Africa. The dyke swarm comprises numerous east-west trending, near vertical, kimberlite dykes (Harris et al., 1979) and in parts is the highest grade kimberlite occurrence in South Africa. There exists a large variation in the grades of the various intrusive phases, from as high as $500 \mathrm{ct} / 100 \mathrm{t}$ in the Main Fissure, to $20 \mathrm{ct} / 100 \mathrm{t}$ in the Changehouse Fissure to zero in the Muil Fissure. The Helam Diamond Mine currently exploits the Main and Changehouse fissures for their diamonds.

Analyses of a diverse suite of disaggregated mantle macrocryst minerals from the Main and Changehouse fissures suggest that the lithosphere beneath this kimberlite occurrence is dominated by harzburgite and lherzolite with a volumetrically significant component of Group I eclogite. The Main Fissure is characterized by abundant harzburgitic, lherzolitic and Group I eclogitic garnet macrocrysts, significant quantities of chromite macrocrysts and a minor megacryst garnet population.
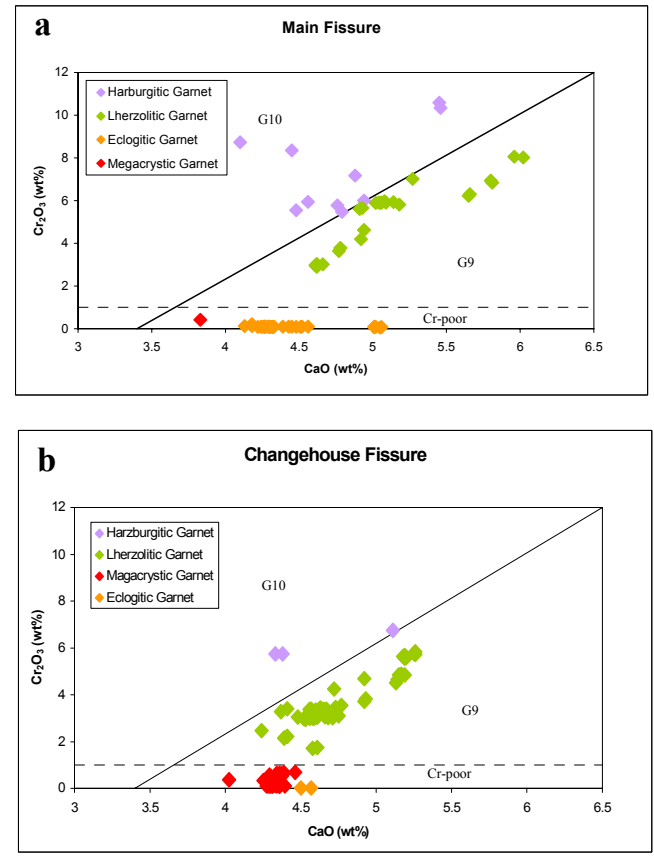

The Changehouse Fissure is also characterized by significant amounts of lherzolitic garnet macrocrysts and chromite macrocrysts, but is distinguished by markedly fewer harzburgitic garnet macrocrysts, the absence of Group I eclogitic macrocrysts and the presence of two low-Cr garnet megacryst populations.

The mineralogical differences between these two kimberlite dykes (figure 1) demonstrates the random nature of sampling of kimberlite magmas and emphasizes the importance of the Group I eclogite in establishing high diamond grade at this locality. It is suggested that the ability of the Main Fissure to sample numerous potentially diamondiferous lithologies, particularly eclogite, has resulted in its exceptionally high grade. The lower grade of the Changehouse Fissure is consistent with the failure of the kimberlite in sampling the Group I eclogitic material. In addition, elevated $\mathrm{TiO}_{2}$ contents associated only with the garnet macrocrysts of the Changehouse Fissure allude to a metasomatic event (that was not sampled during the intrusion of the Main Fissure).
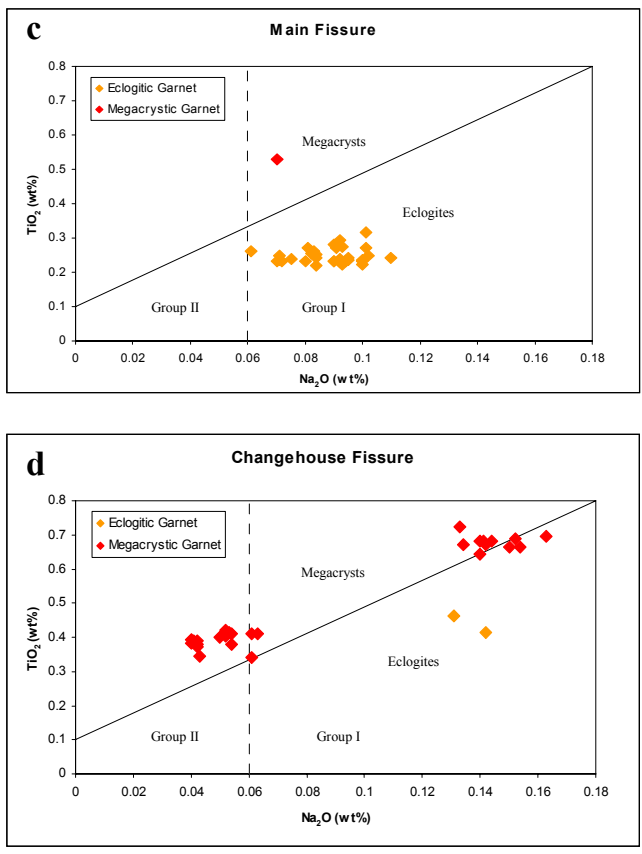

Figure 1: a \& b Garnet macrocryst compositions from the Main and Changehouse fissures; solid line (85\% line) defines a lherzolitic trend at 50 kbars pressure (Gurney \& Zweistra, 1995). c \& d low-Cr garnet compositions. Solid line separates Cr-poor megacrysts and eclogitic garnets (Kimberlite Research Group database, University of Cape Town). 
The physical characteristics of over 350 diamonds have been studied in detail. While octahedra, cubo-octahedra and cuboid diamonds all exist in significant quantities, the majority of the diamonds appear to have been extensively resorbed and commonly occur in the form of tetrahexahedroida (figure 2). The differences in the primary morphologies of the diamonds have been interpreted to reflect differences in their respective growth environments.

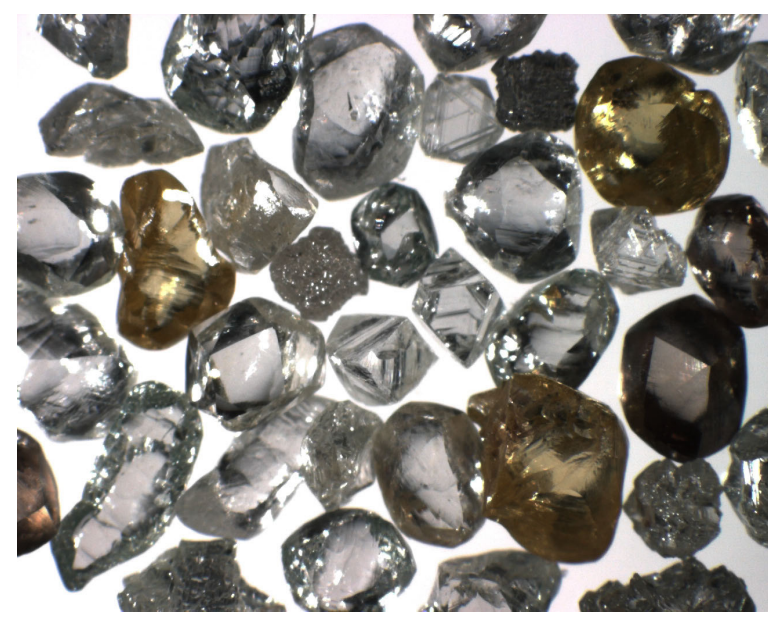

Figure 2: Helam run of mine production, illustrating a variety of crystal morphologies and crystal body coloration. (FOV = $20 \mathrm{~mm})$.

Diamond sub-populations have been identified principally on the basis of differences in their body coloration. Colorless $(65 \%)$, brown $(20 \%)$, green $(9 \%)$, canary-yellow (5\%) and Cape-yellow (1\%) diamonds have been observed. The differences in coloration are either directly or indirectly a result of corresponding differences in their respective chemical characteristics, which have been imposed on the diamonds by their respective crystallization environments. The brown coloration has been interpreted to be a result of crystal deformation. It has been demonstrated that in general those diamonds associated with relatively low nitrogen contents are more susceptible to the processes of deformation. The non-penetrative green coloration has only been observed within diamonds displaying high nitrogen concentrations (up to $2500 \mathrm{ppm}$ ) and mature aggregation states (up to $70 \%$ nitrogen occurring as B aggregate). Consequently it has been suggested that the green coloration is a result of the propitiation of surface lattice disorders in diamonds associated with high nitrogen contents and aggregation states as a result of alpha-decay damage. The yellow coloration is attributed to the presence of N3 centers for high nitrogen (>200ppm) 'Cape-yellow' diamonds, and the presence of dispersed nitrogen atoms for the low nitrogen $(<150 \mathrm{ppm})$ 'canary-yellow' diamonds.
The majority (95\%) of the diamonds are associated with high nitrogen contents and mature nitrogen aggregation states, and have been classified as Type IaAB diamonds on the basis of their infrared absorption properties. These diamonds are interpreted to have an ancient age $(\sim 2.9 \mathrm{Ga})$, and display well constrained time-averaged mantle residence temperatures of between $1090-1100$ ${ }^{\circ} \mathrm{C}$.

Approximately 5\% of the diamond population ('canaryyellow' diamonds) however, is characterized by low nitrogen concentrations ( $>150 \mathrm{ppm})$ and aggregation states assigned to the Type Ib-IaA aggregation series. These natural Type Ib diamonds, while only comprising a small percentage of the total diamond budget, are generally exceedingly rare in nature (Evans, 1992), and thus a contribution of $5 \%$ to the diamond budget is significant and somewhat unusual. Only eclogitic inclusion minerals have been liberated from these natural Type Ib diamonds. In addition, Logan (1999) has shown that these diamonds display highly fractionated carbon isotopic signatures (between $-10.25 \% \mathrm{o}$ and $-19.48 \% \mathrm{o})$. It is reasonable then to ascribe all these Type $\mathrm{Ib}$ diamonds to a separate, younger eclogitic paragenesis.

Detailed investigation into the internal structure and chemical variation of numerous diamond plates (combining Cathodoluminescence and Fourier Transform Infrared studies) reveal that the diamonds are often complexly zoned (figure 3), suggestive of episodic crystallization and complex growth histories within numerous disparate mantle environments. It appears that the majority of the diamonds crystallized within 'closed-system' environments, these diamonds exhibiting progressive depletion in substitutional nitrogen and hydrogen with successive diamond growth. Some diamond plates however show evidence for mantle environments that have repeatedly oscillated from conditions suitable for cubic and octahedral growth respectively. It is suggested that ingress of sulfur- and carbon-saturated fluids, carrying nitrogen, have controlled/modified the chemistry and morphologies of such diamonds. Diamond plates exhibiting large abrupt changes in the concentrations of nitrogen are in support of temporary 'open-system' crystallization for some of the diamonds.

Octahedral and cubic diamonds are interpreted to be representative of diamond crystallization within environments of low and high levels of carbon supersaturation respectively. The large population of cubo-octahedral diamonds represents crystallization within intermediate environments of carbon supersaturation and is characterized by growth sectoral dependence of nitrogen. 


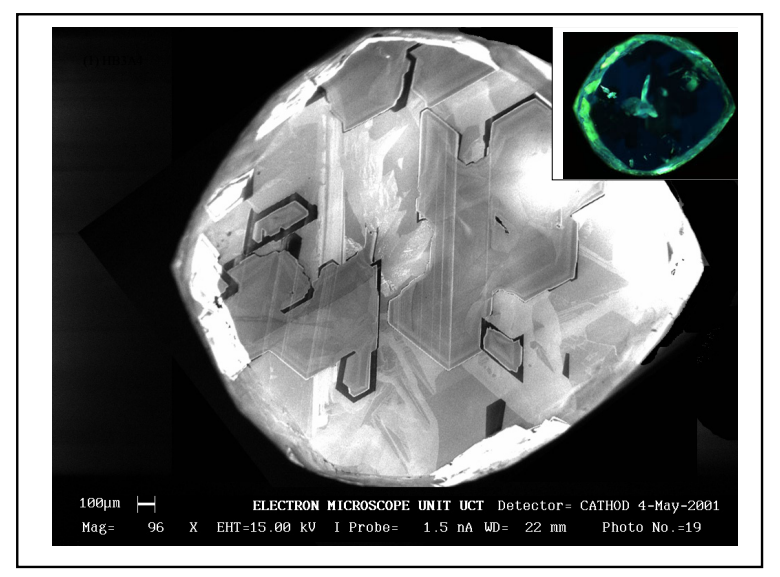

Figure 3: Cathodoluminescence (CL) photomicrograph of diamond HB3A4 (optical CL insert), showing numerous cores of octahedral Type IaAB and Type II diamond surrounded by complexly zoned Type IaAB diamond.

The study of syngenetic mineral inclusions within the diamonds provides evidence in support of multiple diamond source regions. Peridotitic and eclogitic diamond mineral inclusions dominate along with subordinate websteritic and only minor calc-silicate diamond mineral inclusions (Tables 1, $2 \& 3$ ).

Peridotitic diamond mineral inclusions include olivine, chromite, diopside, and high-Ni sulfides, suggesting that the peridotitic diamonds crystallized within chromite harzburgite substrates that were in equilibrium with a high Ni-sulfide melt. The olivine inclusions have 92-94 forsterite contents with restricted ranges of $\mathrm{Cr}_{2} \mathrm{O}_{3}$ $(0.02-0.07$ wt.\%) and $\mathrm{NiO}(0.32-0.42$ wt.\%). Three populations of olivine have been identified on the basis of their respective Mg\#'s. Chromite inclusions are common among the peridotitic diamonds, characterized by high $\mathrm{Cr}_{2} \mathrm{O}_{3}(63.7-69.4 \mathrm{wt} \%)$ contents. Three populations of chromite can also be identified based on differences in their $\mathrm{TiO}_{2}$ and $\mathrm{Al}_{2} \mathrm{O}_{3}$ contents. While two of the chromite populations fall within the range of most other chromite inclusions from world-wide localities (Mayer, 1987), one population of chromite inclusions exhibits relatively enriched $\mathrm{TiO}_{2}$ concentrations $(0.5-0.8$ wt.\%) which tend towards values more commonly associated with phenocrystic chromites. The different populations of olivine and chromite may represent up to three different harzburgitic parageneses. A single diopsidic clinopyroxene was identified, based on its relatively high $\mathrm{Cr}_{2} \mathrm{O}_{3}$ and $\mathrm{MgO}$ content (3.02 wt.\% and $15.2 \mathrm{wt} . \%$ respectively) and low $\mathrm{Na}_{2} \mathrm{O}$ and $\mathrm{Al}_{2} \mathrm{O}_{3}$ contents $(2.74$ wt. $\%$ and 2.11 wt.\% respectively). High Ni-sulfide inclusions are also found in abundance. Inclusions of monosulfide solid solution with $\mathrm{Ni}$-contents greater than 16 wt.\% have all been assigned to the peridotitic parageneses, after Yefimova et al. (1983).

The eclogitic diamonds are characterized by inclusions of Group I eclogitic garnet, $\mathrm{SiO}_{2}$, corundum and low-Ni sulfides, suggesting crystallization within peraluminous, grospyditic substrates. Two populations of eclogitic garnet have been identified, a single eclogitic inclusion from a colorless diamond exhibits a $\mathrm{Mg} \#$ of 57 and $\mathrm{MgO}$ and $\mathrm{FeO}$ contents of 15.4 wt.\% and 10.6 wt.\% respectively, The second population was identified from a 'canary-yellow' diamond, and are characterized by Mg\#'s between 51 and 54, and $\mathrm{FeO}$ and $\mathrm{MgO}$ contents of between $17.0-17.2$ wt.\% and 9.2 - 9.5 wt.\% respectively. A single omphacitic clinopyroxene is assigned to the eclogitic paragenesis due to its relatively high $\mathrm{Na}_{2} \mathrm{O}$ and $\mathrm{Al}_{2} \mathrm{O}_{3}$ contents (5.1 wt.\% and 5.4 wt.\% respectively). This inclusion is virtually free of $\mathrm{Cr}_{2} \mathrm{O}_{3}$ and exhibits a $\mathrm{K}_{2} \mathrm{O}$ content of 0.08 wt.\%. The most notable feature of the eclogitic diamond mineral inclusion suite is the abundance of pure $\mathrm{SiO}_{2}$ and corundum inclusions. Low Ni-sulfide inclusions are also common among the eclogitic diamonds; monosulfide solid solution inclusions with $\mathrm{Ni}$-contents less than $10 \mathrm{wt} . \%$ have been assigned to the eclogitic paragenesis after Yefimova et al. (1983).

The less abundant websteritic diamonds are characterized by inclusions of garnet, clinopyroxene

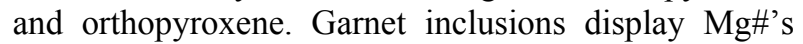
between 77 and 83, with low $\mathrm{Cr}_{2} \mathrm{O}_{3}(0.2-0.3$ wt.\%), low $\mathrm{FeO}(11.0$ - 11.3 wt.\%) and low $\mathrm{MgO}(19.7-20.1$ wt.\%) contents. Two websteritic clinopyroxene inclusions were identified, characterized by high $\mathrm{MgO}$ (approximately 17.5 wt.\%) and $\mathrm{CaO}$ and $\mathrm{Cr}_{2} \mathrm{O}_{3}$ contents of between $22.0-24.1$ wt. $\%$ and $0.08-0.2$ wt.\% respectively. A single orthopyroxene inclusion virtually free of $\mathrm{Cr}_{2} \mathrm{O}_{3}$ and exhibiting $\mathrm{CaO}$ and $\mathrm{Na}_{2} \mathrm{O}$ contents of 0.2 wt. $\%$ and 0.1 wt. $\%$ respectively, has also been assigned to the websteritic paragenesis.

An unusual clinopyroxene inclusion, characterized by high $\mathrm{CaO}, \mathrm{Al}_{2} \mathrm{O}_{3}$ and $\mathrm{Na}_{2} \mathrm{O}$ (20.3 wt.\%, 5.4 wt.\% and 2.2 wt.\% respectively) and low $\mathrm{MgO}$ content (11.9 wt.\%) is similar to Ca-rich pyroxenes from southeastern Australia (Sobolev et al., 1984) and is identical to a calc-silicate inclusion recovered from the Premier Mine, South Africa (Tsai et al., 1979). This inclusion has consequently been assigned to the calc-silicate paragenesis.

The compositions of two unusual garnet diamond mineral inclusions, liberated from a single diamond, are interpreted to represent majorite. An attempt to verify the majorite structure was unsuccessful due to the small 
size of both inclusions. This association is made principally on the appreciably greater $\mathrm{Si}$ content associated with these minerals (between +0.508 -and +0.534 above the ideal 3 cations per formula unit of garnet). This necessitates the existence of $\mathrm{Si}$ in octahedral coordination, and suggests that these 'garnets' host a component of pyroxene in solid solution. Moore \& Gurney (1985) have shown that similar solid solution found among garnets from Monastery Mine is consistent with pressures and temperatures associated with the asthenospheric mantle. The observation of majorite among the diamonds from the Swartruggens Kimberlite Dyke Swarm may provide evidence for an ultra-deep origin for Group II kimberlites.

The study of the diamonds, diamond mineral inclusions and other mantle minerals from the Swartruggens Kimberlite Dyke Swarm provides abundant evidence for a dynamic underlying lithosphere, in which diamond has crystallized episodically over time within numerous disparate mantle environments. It is suggested that the success that the kimberlite dyke system, specifically the Main Fissure, has had in sampling numerous diamond source lithologies has resulted in its exceptionally high diamond grade.

Table 1: Selected chemical analyses for silicate inclusions from some Helam diamonds. olv = olivine, $\mathrm{cpx}=$ clinopyroxene, $\mathrm{gnt}=$ garnet, $\mathrm{opx}=$ orthopyroxene, $\mathrm{p}=$ peridototitic, $\mathrm{e}=$ eclogitic, $\mathbf{w}=$ websteritic, $\mathrm{cs}=$ calc silicate paragenesis.

\begin{tabular}{|c|c|c|c|c|c|c|c|c|c|c|c|}
\hline & $\begin{array}{l}\text { olv-p } \\
\text { HM3B4a }\end{array}$ & $\begin{array}{l}\text { cpx-p } \\
\text { HM007a }\end{array}$ & $\begin{array}{l}\text { gnt-e } \\
\text { HM1B2a }\end{array}$ & $\begin{array}{l}\text { gnt-e } \\
\text { HM006c }\end{array}$ & $\begin{array}{l}\text { cpx-e } \\
\text { HM018a }\end{array}$ & $\begin{array}{l}\text { gnt-w } \\
\text { HM3A5b }\end{array}$ & $\begin{array}{l}\text { cpx-w } \\
\text { HM008a }\end{array}$ & $\begin{array}{l}\text { opx } \\
\text { HM108a }\end{array}$ & $\begin{array}{l}\text { cpx-cS } \\
\text { HM3B11c }\end{array}$ & $\begin{array}{l}\text { Majorite } \\
\text { HM009a }\end{array}$ & $\begin{array}{l}\text { Majorite } \\
\text { HM009b }\end{array}$ \\
\hline \multicolumn{12}{|c|}{ Oxides } \\
\hline $\mathrm{SiO}_{2}$ & 40.42 & 54.36 & 40.38 & 38.34 & 54.53 & 42.13 & 54.54 & 57.60 & 52.99 & 47.44 & 47.98 \\
\hline $\mathrm{TiO}_{2}$ & N.D. & N.D. & 0.29 & 0.32 & 0.21 & 0.23 & 0.18 & N.D. & 0.52 & 0.60 & 0.60 \\
\hline $\mathrm{Al}_{2} \mathrm{O}_{3}$ & N.D. & 2.11 & 21.66 & 23.17 & 7.81 & 22.95 & 0.26 & 0.06 & 5.35 & 10.19 & 9.71 \\
\hline $\mathrm{Cr}_{2} \mathrm{O}_{3}$ & 0.02 & 3.02 & 0.09 & 0.06 & 0.05 & 0.21 & 0.15 & 0.40 & 0.06 & 2.19 & 2.20 \\
\hline $\mathrm{FeO}$ & 5.96 & 2.13 & 15.43 & 17.08 & 5.97 & 11.05 & 2.62 & 8.04 & 6.82 & 3.33 & 3.39 \\
\hline $\mathrm{MnO}$ & 0.09 & 0.06 & 0.32 & 0.35 & 0.10 & 0.43 & 0.06 & 0.05 & 0.06 & 0.18 & 0.20 \\
\hline MgO & 54.80 & 15.50 & 10.60 & 9.50 & 11.37 & 19.72 & 17.50 & 34.13 & 11.87 & 13.67 & 13.70 \\
\hline $\mathrm{CaO}$ & 0.03 & 19.23 & 11.38 & 11.02 & 14.23 & 3.10 & 24.16 & 0.22 & 20.33 & 20.18 & 20.45 \\
\hline $\mathrm{Na}_{2} \mathrm{O}$ & N.D. & 2.74 & 0.12 & 0.11 & 5.10 & 0.12 & 0.33 & 0.12 & 2.19 & 0.99 & 1.00 \\
\hline $\mathrm{K}_{2} \mathrm{O}$ & N.D. & N.D. & N.D. & N.D. & 0.08 & N.D. & N.D. & N.D. & N.D. & N.D. & N.D. \\
\hline $\mathrm{NiO}$ & 0.37 & 0.05 & N.D. & N.D. & N.D. & N.D. & N.D. & N.D. & N.D. & N.D. & N.D. \\
\hline Total & 101.69 & 99.20 & 100.27 & 99.95 & 99.45 & 99.94 & 99.85 & 100.62 & 100.19 & 98.77 & 99.23 \\
\hline \multicolumn{12}{|c|}{ Cations } \\
\hline Si & 0.96 & 1.99 & 3.01 & 2.90 & 1.98 & 3.02 & 1.99 & 1.99 & 1.94 & 3.51 & 3.53 \\
\hline $\mathrm{Ti}$ & 0.00 & 0.00 & 0.02 & 0.02 & 0.01 & 0.01 & 0.01 & 0.00 & 0.01 & 0.03 & 0.03 \\
\hline Al & 0.00 & 0.09 & 1.90 & 2.06 & 0.33 & 1.94 & 0.01 & 0.00 & 0.23 & 0.89 & 0.84 \\
\hline $\mathrm{Cr}$ & 0.00 & 0.09 & 0.01 & 0.00 & 0.00 & 0.00 & 0.00 & 0.01 & 0.00 & 0.13 & 0.13 \\
\hline $\mathrm{Fe}^{2+}$ & 0.12 & 0.07 & 0.89 & 0.90 & 0.18 & 0.62 & 0.08 & 0.23 & 0.21 & 0.14 & 0.15 \\
\hline $\mathrm{Fe}^{3+}$ & 0.00 & 0.00 & 0.08 & 0.18 & 0.00 & 0.04 & 0.00 & 0.00 & 0.00 & 0.06 & 0.06 \\
\hline$M n$ & 0.00 & 0.00 & 0.02 & 0.02 & 0.00 & 0.03 & 0.00 & 0.00 & 0.00 & 0.01 & 0.01 \\
\hline $\mathbf{M g}$ & 1.95 & 0.84 & 1.18 & 1.07 & 0.61 & 2.10 & 0.95 & 1.76 & 0.65 & 1.51 & 1.50 \\
\hline $\mathrm{Ca}$ & 0.00 & 0.75 & 0.91 & 0.89 & 0.55 & 0.24 & 0.94 & 0.01 & 0.80 & 1.60 & 1.61 \\
\hline $\mathrm{Na}$ & 0.00 & 0.19 & 0.02 & 0.02 & 0.36 & 0.02 & 0.02 & 0.01 & 0.16 & 0.14 & 0.14 \\
\hline K & 0.00 & 0.00 & 0.00 & 0.00 & 0.00 & 0.00 & 0.00 & 0.00 & 0.00 & 0.00 & 0.00 \\
\hline $\mathrm{Ni}$ & 0.01 & 0.00 & 0.00 & 0.00 & 0.00 & 0.00 & 0.00 & 0.00 & 0.00 & 0.00 & 0.00 \\
\hline Total & 3.04 & 4.02 & 8.03 & 8.06 & 4.03 & 8.01 & 4.01 & 4.01 & 4.01 & 8.02 & 8.02 \\
\hline Mg\# & 94.25 & 92.84 & 57.13 & 54.33 & 77.25 & 77.25 & 92.25 & 88.33 & 75.63 & 91.40 & 91.81 \\
\hline
\end{tabular}


Table 2: Selected chemical analyses for oxide inclusion minerals. $\operatorname{cor}=$ corundum, chr $=$ chromite.

\begin{tabular}{lllllllll} 
& cor & cor & $\mathrm{SiO}_{2}$ & $\mathrm{SiO}_{2}$ & $\mathrm{chr}$ & $\mathrm{chr}$ & chr & chr \\
& HM2B2k & HM2B2n & HM114c & HM119b & HM031a & HM055a & HM067c & HM1A9f \\
\hline $\mathrm{SiO}_{2}$ & N.D. & N.D. & 99.13 & 99.24 & 0.14 & 0.13 & 0.13 & 0.10 \\
$\mathrm{TiO}_{2}$ & N.D. & N.D. & N.D. & N.D. & 0.76 & 0.02 & 0.82 & 0.46 \\
$\mathrm{Al}_{2} \mathrm{O}_{3}$ & 98.90 & 98.85 & 0.02 & N.D. & 4.69 & 4.80 & 4.83 & 4.55 \\
$\mathrm{Cr}_{2} \mathrm{O}_{3}$ & N.D. & N.D. & N.D. & N.D. & 64.30 & 66.91 & 64.19 & 66.11 \\
$\mathrm{FeO}$ & N.D. & N.D. & N.D. & 0.08 & 13.52 & 14.87 & 16.23 & 15.35 \\
$\mathbf{M n O}$ & N.D. & N.D. & 0.01 & 0.01 & 0.20 & 0.28 & 0.22 & 0.28 \\
$\mathbf{M g O}$ & N.D. & N.D. & N.D. & N.D. & 16.09 & 12.93 & 13.47 & 12.96 \\
$\mathbf{C a O}$ & N.D. & N.D. & 0.06 & 0.40 & N.D. & N.D. & N.D. & N.D. \\
$\mathbf{N a} 2$ & N.D. & N.D. & 0.12 & 0.02 & N.D. & N.D. & N.D. & N.D. \\
$\mathrm{K}_{2} \mathrm{O}$ & N.D. & N.D. & 0.02 & N.D. & N.D. & N.D. & N.D. & N.D. \\
$\mathbf{N i O}$ & N.D. & N.D. & N.D. & 0.03 & 0.11 & 0.03 & 0.08 & 0.11 \\
Total & $\mathbf{9 8 . 9 0}$ & $\mathbf{9 8 . 8 5}$ & $\mathbf{9 9 . 3 6}$ & $\mathbf{9 9 . 7 8}$ & $\mathbf{9 9 . 8 1}$ & $\mathbf{1 0 0 . 0 5}$ & $\mathbf{9 9 . 9 7}$ & $\mathbf{9 9 . 9 2}$
\end{tabular}

Table 3: Selected chemical analyses for sulfide inclusion. mss $=$ monosulfide solid solution, pyrr $=$ pyrrhotite, pnt $=$ pentlandite, $\mathbf{h z}=$ heazlewoodite .

\begin{tabular}{lllllllll} 
& mss & mss & pyrr & pyrr & pnt & pnt & hz & hz \\
& HM3C10a & HB3B4d & HM059a & HM124a & HM3B9d & HM3B10a & HM235a & HM3B7a \\
\hline $\mathbf{S}$ & 38.13 & 36.38 & 39.24 & 38.64 & 36.70 & 34.18 & 35.34 & 35.32 \\
$\mathbf{C r}$ & N.D. & N.D. & N.D. & N.D. & N.D. & N.D. & N.D. & N.D. \\
$\mathbf{M n}$ & N.D. & N.D. & N.D. & N.D. & N.D. & N.D. & N.D. & N.D. \\
$\mathbf{F e}$ & 54.75 & 41.61 & 58.09 & 58.06 & 27.47 & 27.76 & 1.48 & 2.49 \\
$\mathbf{C o}$ & 0.77 & 2.55 & 0.29 & 0.20 & 1.12 & 0.37 & 0.14 & 1.01 \\
$\mathbf{N i}$ & 5.31 & 19.25 & 1.13 & 2.21 & 33.91 & 36.60 & 62.67 & 61.03 \\
$\mathbf{C u}$ & 0.31 & 0.07 & N.D. & 0.11 & 0.10 & 0.05 & 0.36 & 0.07 \\
Zn & N.D. & N.D. & N.D. & N.D. & N.D. & N.D. & N.D. & N.D. \\
Total & $\mathbf{9 9 . 2 7}$ & $\mathbf{9 9 . 8 6}$ & $\mathbf{9 8 . 7 6}$ & $\mathbf{9 9 . 2 2}$ & $\mathbf{9 9 . 2 9}$ & $\mathbf{9 8 . 9 7}$ & $\mathbf{9 9 . 9 9}$ & $\mathbf{9 9 . 9 3}$
\end{tabular}

\section{REFERENCES}

Evans, T., 1992. Aggregation of nitrogen in diamond. In: J.E. Field (ed.), The Properties of Natural and Synthetic Diamond. Academic Press., pp.259-290.

Harris, J.W., Hawthorne, J.B. \& Oosterveld, M.M., 1979. Regional and local variations in the characteristics of diamonds from some southern African kimberlites. Proc. $2^{\text {nd }}$ Int. Kimb. Conf. pp. 27-41.

Klump, J., 1995. A pilot study of the Swartruggens kimberlite dyke swarm. Unpubl. Honors Thesis. University of Cape Town.

Logan, F., 1999. A Mineralogical and Isotope Study of Macrodiamonds from the Helam Mine, South Africa. Unpubl. Honors Thesis. Queens University.

Meyer, H.O.A., 1987. Inclusions in diamond. In: P.H. Nixon, (E.). Mantle Xenoliths. John Wiley \& Sons. Pp. $501-$ 523.
Sobolev, N.V., Yefimova, E.S., Laverent'yev, Yu.G., \& Sobolev, V.S., 1984. Dominant calc-silicate association of crystalline inclusions in placer diamonds from southeastern Australia. Dokl. Akad. Nauk. S.S.S.R. 274, 148-153.

Tsai, H.M., Meyer, H.O.A., Moreau, J. \& Milledge, H.J., 1979. Mineral inclusions in diamond: Premier, Jaggersfontein and Finsch kimberlites, South Africa, and Williamson Mine, Tanzania. In: F.R. Boyd \& H.O.A. Meyer (Eds), Kimberlites, Diatremes and Diamonds: Their Geology, Petrology and Chemistry. American Geophysical Union, Washington D.C., pp. 16-26.

Yefimova, E.S., Sobolev, N.V., \& Pospelova, L.N.1983., Sulfide inclusions in diamond and specific features of their paragenesis. Zap. Vses. Mineral. Obsh. 112, 300 -310 (in Russian).

Contact: N Mc Kenna, PO Box 82232, Southdale,

Johannesburg, 2135, E-mail:

neil.mckenna@debeersgroup.com 